DOI https://doi.org/10.18551/rjoas.2018-09.40

\title{
ANALYSIS OF FACTORS AFFECTING THE RISK OF FAILURE IN ACHIEVING THE PROJECT OBJECTIVES IN ACCURATE TIME AND QUALITY ON THE CONSTRUCTION PROJECT OF THE PAGERWOJO BRIDGE IN TULUNGAGUNG DISTRICT
}

\author{
Azis Subandiyah, Purwanto Anang* \\ Civil Engineering Majoring Construction Management, National Institute of Technology, \\ Malang, Indonesia \\ *E-mail: anangp865@gmail.com \\ ORCID: 0000-0001-5963-4284
}

\begin{abstract}
This research was conducted to determine the factors that directly or indirectly affect the risk of failure in achieving the project objectives in accurate time and quality on the construction project of the Pagerwojo Bridge in Tulungagung District and to get the most dominant factors affecting it. Data analysis method used is factor analysis and path analysis to the answers from the questionnaire distributed to 43 respondents consisting of the contractor, owner and supervisory consultant. Based on the findings of the research, all factors have an effect directly or indirectly and simultaneously on the failure in achieving the time target. Individually, the factors that have significant and direct effect on the failure in achieving the time target are human resources, equipment, and work environment. The factors that have significant and direct effect on the failure in achieving the quality target are time target factor, material, equipment, and work environment. The factors that have indirect and significant effect on the failure in achieving the time target and quality target are human resources, materials, equipment and work environment. The dominant factor that has direct or indirect effect on the failure in achieving of time target and quality target is the human resources factor. The strategy to overcome the problem is that the contractor must employ skilled and qualified human resources in their field in accordance with the needs of the construction project. It is expected that further research will add other variables such as skilled worker to get more varied research findings.
\end{abstract}

\section{KEY WORDS}

Objectives, project, time, quality.

The implementation of a project experiences three constraints, i.e. cost, time and quality. These three constraints are defined as project targets, which are defined as accurate cost, accurate time, and accurate quality (Chen et. al., 2009). The success of a project is related to the extent to which these three targets can be met. Project management is the process in managing the project through the management, allocation and scheduling of resources in the project in order to achieve these goals.

As part of the project management process, good planning and control do not guarantee the realization of project objectives. There is always the possibility of failure in achieving an objective or there is always the uncertainty about the decision that has been taken. A condition, which arises because of the uncertainty with all the consequences that might occur unfavorably, is called risk. Unfortunate consequences refer to the failure in achieving the project objectives, i.e. the accurate cost, accurate time, and accurate quality.

The project has unique characteristics so it requires a number of assumptions to estimate data and information that are not yet available during the process; from the planning stage to the implementation stage. These assumptions and estimates support the emergence of this uncertainty. The risks experienced by a project depend on these assumptions and estimates. The risks that will be experienced in a project are heavier because the nature of the project is that it only runs in a non-repetitive implementation period. 
Regarding to this matter, risk management is needed to look at the risks experienced by a project and to review its effects on project objectives. Furthermore, handling can be planned to minimize the adverse consequences so that it will support the realization of the project objectives.

Those that are included in the risk management stage are risk management planning, risk identification, risk analysis, risk handling and risk monitoring, (Marvin et al., 2009). Risk identification is the first step in implementing risk management and is an important step in project implementation. By identifying risks in the implementation process of a construction project, any risks that occur during the project implementation will be known; starting from the project begins until the project is handed over. Furthermore, it will find out how potential these risks are in influencing the failure to achieve project objectives.

It is not much different from the development of other projects in Indonesia. The construction projects in Tulungagung District also experienced many constrains in the time and quality accuracy. One of them is the construction project of the Pagerwojo Bridge in Tulungagung District which was built in the fiscal year of 2016 in which the project cannot be completed in accurate time and quality in its implementation. The failure in achieving time and quality targets is not yet known with certainty. Therefore, risk identification in the construction project of the Pagerwojo Bridge in Tulungagung District also needs to implement time and quality accuracy because it is one form of construction project that has a number of risks in its implementation. As in other construction projects, the risks involved have the same potential risks as other construction projects such as buildings.

Identifying risks earlier with an appropriate analysis is expected to support the increased possibility in achieving better project objectives, especially the time and quality accuracy.

In connection with the above background, it requires identification of any factors affecting the risk of failure in achieving the project objectives on the construction project of the Pagerwojo Bridge in Tulungagung District in accurate time and quality. Furthermore, research findings can be used for business owners in the construction sector, especially those engaged in road and bridge construction in analyzing risks and taking appropriate steps to deal with these risks.

\section{THEORETICAL FRAMEWORK}

According to Soeharto (2001), "project management is planning, organizing, leading, and controlling company resources to achieve predetermined short-term objectives. Furthermore, project management uses a vertical and horizontal system approach and hierarchy (activity flows)".

A project is an activity that is unique and complex and includes all activities in it that have a purpose and must be completed in accurate time, accurate budget, and accurate specifications (Soeharto, 2001).

Parts of project operations that have a high risk indicate that the part is not handled properly due to lack of resource capabilities, both from the project manager and the project organization.

In the context of the project, the negative consequences of project risk that is defined as failure in achieving project objectives include:

- Realization of project costs that is not in accordance with the estimated costs;

- Realization of project implementation time that is not in accordance with the estimated schedule;

- Realization of the quality of work that does not meet the technical specifications.

Risk management is a very useful tool for project management in supporting project control to avoid situations that lead to cost overruns, delays in achieving schedules, or inability to meet the specified performance (Soeharto, 2001).

As explained in the previous section, construction projects are a high-risk business field (Barrie et. al., 1984). Risk can stop the project, lead to delays, and also lead to cost overruns. Risks that cause bad changes in project aspects are time estimate, cost estimate, 
and design technology. The potential weight of the project risk is based on the frequency parameter of the occurrence of the risk to the project objectives. Thus, information on risks that have the potential to occur in water construction projects needs to be supported by information on how much effect these risks have on the failure in achieving project objectives.

To understand the concept of risk in construction projects, understanding the risks is required. The following describes the meaning of risk according to several sources. Risk is defined as uncertainty about the occurrence of an event. Another definition explains that risk is a condition where there are possible economic or financial gains/losses, physical damage or injury, and delays, as a consequence of uncertainty during an activity (Cooper and Emory, 1999).

Understanding risk in the context of a project is that the risk can be defined as a description of the consequences that are not profitable, financially and physically, as the results and decisions taken or due to environmental conditions in which a project is located. When it is associated with the concept of opportunity, risk is an opportunity for an unexpected condition to occur with all possible consequences which can cause project delays or failures. Kerzner (2006) described the concept of risk to a project as a measure of probability and consequences and failure in achieving predetermined project objectives.

From some of the above understanding, it can be concluded that risk is a condition that arises because of uncertainty with the chance of certain events. Its occurrence will have unfavorable consequences. Furthermore, the risk to the project is a condition in the project that arises due to uncertainty with certain event opportunities. Its occurrence will result in physical and financial consequences that are not profitable for the achievement of the project objectives, i.e. the cost, time and quality of the project.

Although the risk has a close relation with uncertainty but both have differences. Uncertainty is a condition where lack of knowledge, information, or understanding of a decision and its consequences occur. Risk arises because of uncertainty, in which uncertainty results in doubts in predicting the possibility of future results. It is said that the higher the level of uncertainty, the higher the risk (Kerzner, 2006).

Risk management is an activity carried out to respond to the risks (through a risk analysis plan or other form of observation) to minimize possible adverse consequences. Therefore, risk must be defined in the form of a relative plan or procedure. Kerzner (2006) suggested the notion of risk management as a series of activities related to risks, which includes risk planning, risk assessment (identification and analysis), risk handling and risk monitoring.

Schedule is the elaboration of project planning into a sequence of steps for the implementation of work that aims to achieve the objectives. The time factor has been included in the schedule. The schedule shows the estimated time required to complete each work package and the relationship between work packages (which work packages must be completed before the other packages start). The arrangement of this relationship is called a network. The project must be carried out within the limits of the specified time and deadline (Soeharto, 2001).

Lim and Niem (1995) mentioned that quality is a characteristic of a good or service that shows its ability in satisfying the needs of the owner/project owner; either expressed and implied. The quality needed will always follow the development of human thoughts and feelings.

What is meant by population is a collection of all individuals with a predetermined quality in which the quality or characteristics are called variables. What is meant by a sample is a collection of sampling units that are taken and are sub-populations (Sugiono, 2006).

Statistics is the science and art of development and the application of the most effective method to determine the possibility of error in drawing a conclusion in which the estimate can be predicted based on mathematical probability (Supranto, 2001).

Validity is a measure that shows the levels of validity of an instrument, (Green, 2004). An instrument is considered to be valid if it can reveal the data from variables that are examined appropriately. The high and low validity of the instrument shows the extent to 
which the data that has been collected does not deviate from the description of the validity (Riduwan, 2005). Whether or not an instrument is valid, it can be known by comparing the correlation index of Product Moment Person with a significant level of 0.05 (5\%) as its critical value by comparing $r$ count with $r_{\text {table }}$, the validity of the instrument can be determined by the following criteria:

$r_{\text {count }}>r_{\text {table: }}$ valid, $r$ count $<r_{\text {table: }}$ invalid

Reliability is an index that shows the extent to which an instrument can be trusted or reliable. In other words, reliability shows the consistency of an instrument in measuring the same things (Singarimbun and Effendi, 2006). In this research, reliability test is carried out by using the Cronbach's Alpha approach. An instrument is considered to be reliable if the value of Cronbach's Alpha is > 0.6.

Conceptually, a factor is an uncertain condition with a certain chance of an event in which-if it occurs-it will cause unfavorable consequences. The concept of factors is defined as independent variables (XI, X2, X3, etc). The definition of independent variable is a variable that is the cause of changes or the emergence of dependent variable (Sugiyono, 2006).

Factor analysis is an analysis commonly given to classes in multivariate statistical methods whose main purpose is to reduce data and summarize it. The aim is to analyze the interrelationships between a number of large variables (test, score, test item, questionnaire) and then explain these variables according to their size in the form of factors. In addition, factor analysis is a technique or method that connects the dependence of all simultaneous variables.

Mathematically, factor analysis has several similarities with multiple regression analysis in which each variable describes such a linear combination of principal factors. The covariance variable is term from a small number of shared factors plus a special factor from another variable.

The analysis technique used is Path Analysis which aims to examine the questions related to the factors affecting the risk of failure in achieving the project objectives in accurate time and quality on the construction project of the Pagerwojo Bridge in Tulungagung District and to determine the most dominant factors affecting it (Solimun and Rinaldo, 2008).

\section{METHODS OF RESEARCH}

Research is a scientific way to solve a problem and to penetrate the limits of human ignorance. Research activities are carried out by collecting and processing the existing facts so that they can be communicated by the researcher and the findings can be enjoyed and used for the benefit of humans. Based on the method, this research includes the type descriptive research which aims to get what factors affecting the risk of failure in achieving the project objectives in accurate time and quality in the construction project of the Pagerwojo Bridge in Tulungagung District and the most dominant factors affecting it.

This research applied survey method by collecting opinions, experiences and attitudes of respondents to find out the problems that have been experienced in the work of construction project of the Pagerwojo Bridge in Tulungagung District by taking primary data through questionnaires and secondary data from related institutions. To find out factors affecting the risk of failure in achieving the project objectives in accurate time and quality on the construction project of the Pagerwojo Bridge in Tulungagung District, the factors are then determined and then by determining the variables to be used as the items to be measured in the form of a questionnaire.

The setting of this research is the construction project of the Pagerwojo Bridge in Tulungagung District which was built in the fiscal year of 2016.

Research Variables:

- The independent variables (X) consist of: Finance (X1), Human Resources (X2), Material (X3), Equipment (X4), Work Implementation Method (X5), Design Changes (X6), and Work Environment (X7); 
- The dependent variables consist of (Y): Accurate Time (Y1) and Accurate Quality (Y2).

The questionnaire used for data collection contains statement items relating to any factors affecting the risk of failure in achieving the project objectives in accurate time and quality on the construction project of the Pagerwojo Bridge in Tulungagung District. In addition, to determine the most dominant factors affecting it, the Likert scale is used with a range of 1 to 5 (very not influential - very influential), so number one is the respondent's very negative response code to one of the questions, while the number five is the respondent's very positive code to one of the questions.

The data obtained from the results of the survey (questionnaire) will be processed to obtain information in the form of tables. The processed data results are used to answer questions in the research problems. The data processing should pay attention to the type of the data collected by concentrating on the objectives to be achieved. The accuracy in the analysis technique greatly influences the accuracy of the findings of the research. The data analysis technique applied is factor analysis and path analysis. The results of the questionnaire data with a range of 1 to 5 from each of these variables are then repeated, so that each variable containing several indicators will produce only one score which is then analyzed using factor analysis and Path analysis. Data processing is performed with the use of the Statistical Package and Service Solution (SPSS) 15 program for Windows.

\section{RESULTS AND DISCUSSION}

Finance Variable $(\mathrm{X} 1)$ is formed by manifest variables consisting of: late payment by the contractor to the worker (X1.1), late payment by the contractor to supplier (X1.2), late payment by the owner to the contractor (X1.3), contractor's financial capability (X1.4), and the use of contract down payment (X1.5).

Human Resources Variable (X2) is formed by manifest variables consisting of: availability of human resources (X2.1), the HR cannot coordinate well (X2.2), HR have no major responsibility (X2.3), HR do not have good expertise (X2.4), estimator behavior is less experienced (X2.5), and HR productivity is quite low (X2.6).

Material Variable $(\mathrm{X} 3)$ is formed by manifest variables consisting of: material deficiency (X3.1), material damage and change (X3.2), delay in delivering the material (X3.3), material scarcity (X3.4), waiting for the results of the test by the owner (X3.5), the absence of material testing in the laboratory (X3.6), and the deviation of material usage from the specifications (X3.7).

Table 1 - The Results of OLS of the First Equation

\begin{tabular}{llll}
\hline Independent Variables & Beta & $\mathrm{t}_{\text {count }}$ & Sig. t \\
\hline Finance (X1) & -0.149 & -1.513 & 0.139 \\
Human Resources (X2) & 0.383 & 3.187 & 0.003 \\
Material (X3) & 0.276 & 2.626 & 0.013 \\
Equipment (X4) & 0.317 & 2.304 & 0.027 \\
Work Implementation Method (X5) & -0.008 & -0.080 & 0.937 \\
Design Change (X6) & 0.185 & 1.794 & 0.081 \\
Work Environment (X7) & 0.257 & 2.125 & 0.041 \\
\hline
\end{tabular}

$\mathrm{R}^{2}=0.723$

$t_{\text {table }}=2.030$

$t_{\text {table }}=2.365$

Dependent Variable $=$ Time Target $(\mathrm{Y} 1)$

Equipment Variable (X4) is formed by manifest variables consisting of: inadequate force from the operator (X4.1), limited number of equipment (X4.2), equipment capability is not suitable to serve the volume of the work (X4.3), delay in delivering the equipment (X4.4), and the existing equipment is often damaged (X4.5).

Work Implementation Method Variable (X5) is formed by manifest variables consisting of: the work is not carried out based on its sequences and stages (X5.1), the implementation 
of work is not according to the specifications (X5.2), and the work is carried out appropriately and correctly (X5.3)

Design Change Variable $(\mathrm{X} 6)$ is formed by manifest variables consisting of: frequent changes in design by the owner (X6.1), delay in the process of change from planning (X6.2), and initial planning is not fulfilled (X6.3).

Work Environment Variable (X7) is formed by manifest variables consisting of: road safeguard of the bridge (X7.1), frequent rain (X7.2), bridge surrounding conditions $(X 7.3)$ and topographic circumstances (X7.4).

Table 2 - The Results of OLS of the Second Equation

\begin{tabular}{llll}
\hline Independent Variables & Beta & $\mathrm{t}_{\text {count }}$ & Sig. t \\
\hline Finance (X1) & 0.041 & 0.392 & 0.698 \\
Human Resources (X2) & 0.384 & 2.617 & 0.015 \\
Material (X3) & 0.357 & 2.518 & 0.020 \\
Equipment (X4) & 0.372 & 2.601 & 0.019 \\
Work Implementation Method (X5) & 0.037 & 0.349 & 0.729 \\
Design Change (X6) & 0.104 & 0.937 & 0.355 \\
Work Environment (X7) & 0.323 & 2.431 & 0.020 \\
Time Target (Y1) & 0.363 & 2.081 & 0.045 \\
\hline
\end{tabular}

$\mathrm{R}^{2}=0.714$

$t_{\text {table }}=2.032$

$t_{\text {table }}=2,306$

Dependent Variable $=$ Quality Target $(\mathrm{Y} 2)$

\section{CONCLUSION AND SUGGESTIONS}

Based on the findings of the research and discussion described in the previous chapter, the following conclusions can be drawn:

Based on the F-test results, it was found that all (X1), (X2), (X3), (X4), (X5), (X6), and (X7) factors have an effect directly or indirectly and simultaneously on the failure in achieving the time target with $F_{\text {count }}=13.057>F_{\text {table }}=2.365$, and quality target with $F_{\text {count }}=10.590>$ $F_{\text {table }}=2.306$. However, individually, the factors that have significant and direct effect on the failure in achieving the time target are human resources with $t_{\text {count }}=2.187>t_{\text {table }}=2.030$, material with $t_{\text {count }}=2.626>t_{\text {table }}=2.030$, equipment with $t_{\text {count }}=2.304>t_{\text {table }}=2.030$, and work environment with $t_{\text {count }}=2.125>t_{\text {table }}=2.030$. In addition, the factors that have significant and direct effect on the failure in achieving the quality target are time target factor with $t_{\text {count }}=2.081>t_{\text {table }}=2.032$, human resources with $t_{\text {count }}=2.617>t_{\text {table }}=2.032$, material with $t_{\text {count }}=2.518>t_{\text {table }}=2.032$, equipment with $t_{\text {count }}=2.601>t_{\text {table }}=2.032$, and work environment with $t_{\text {count }}=2.431>t_{\text {table }}=2.032$. Moreover, the factors that have indirect and significant effect on the failure in achieving the time target and quality target are Human Resources (X2), Material (X3), Equipment (X4) and Work Environment (X7), respectively amounted to $0.139,0.100,0.115$, and 0.093 .

The dominant factor that has direct or indirect effect on the failure in achieving of time target and quality target is the human resources factor with $\beta$ standardized coefficients of 0.383 and 0.384 respectively.

Strategies to overcome the risk of failure in achieving the project objectives in accurate time and quality on the construction project of the Pagerwojo Bridge in Tulungagung District include:

- The contractor must use skilled human resources and experts in their respective field according to the needs of construction project of the Pagerwojo Bridge in Tulungagung District;

- The contractor must bring in rental equipment with good conditions at the work site;

- Before the implementation of the work, it is expected that the contractor conducts material testing in the laboratory so that the quality of the material used is in accordance with the applicable specifications and standards; 
- Build the road safeguard of the bridge properly and in accordance with the needs of bridge construction.

Suggestions:

- Employing skilled human resources who have high productivity, responsibility in completing work, and experience accompanied by a certificate of skill. If skilled labor is limited, it is advisable to use skilled labor from other regions;

- Before starting the work, the contractor must ensure that all work equipment is in good condition;

- Conducting laboratory tests on material to be used in project implementation;

- Building the road safeguard of the bridge appropriately;

- Future research is expected to add other variables such as skilled labor and so forth to get more varied research results.

\section{REFERENCES}

1. Barrie, S.D., Paulson, J.R., \& Boyd, C. (1984), Manajemen Konstruksi Profesional, Edisi II, Penerbit Erlangga, Jakarta.

2. Chen, C. C., Law, C. C., \& Yang, S. C. (2009). Managing ERP implementation failure: a project management perspective. IEEE transactions on engineering management, 56(1), 157-170.

3. Cooper, R. D., \& Emory, C. W. (1999). Metode Penelitian Bisnis. Alih Bahasa: Soetjipto, W dan Wikarya, U. Penerbit Erlangga. Jakarta.

4. Green, P. (2004). Green's medical symptom validity test. Paul Green.

5. Kerzner. (2006). Project Management, A System Approach to Planning, Scheduling, and Controling. Ninth Ed. John Wiley \& Sons, Inc. USA.

6. Lim, T.E., \& Niem, B.C. (1995), Quality Management System, assessment to ISO 9000:1994 series, Singapore.

7. Marvin, H. J. P., Kleter, G. A., Frewer, L. J., Cope, S., Wentholt, M. T. A., \& Rowe, G. (2009). A working procedure for identifying emerging food safety issues at an early stage: Implications for European and international risk management practices. Food control, 20(4), 345-356.

8. Riduwan. (2005). Dasar-Dasar Statistik, Alfabeta Bandung, Singarimbun, M., \& Effendi, S. (2006). Metode Penelitian Survai, LP3ES, Jakarta

9. Soeharto, I. (2001). Manajemen Proyek Dari Konseptual Sampai Operasional. Erlangga. Jakarta.

10. Solimun, N., \& Rinaldo, A. A. (2006). Permodelan Persamaan Struktural Pendekatan PLS dan SEM. Modul Pelatihan Aplikasi Software Smart PLS dan AMOS, Fakultas MIPA dan Program Pascasarjana, Universitas Brawijaya Malang.

11. Sugiyono, (2006). Statistika untuk Penelitian, CV ALFABETA Bandung.

12. Supranto, J. (2001). Statistik Teori Dan Aplikasi Jilid 2, Penerbit Erlangga Jakarta. 